\title{
新設着工におけるプレハブ戸建持家建替住宅と購入者の特性に関する研究 A STUDY ON THE CHARACTERISTICS OF THE REBUILT DETACHED OWNED HOUSES AND PURCHASERS OF PREFABRICATED HOUSING IN THE NEWLY BUILT MARKET
}

\author{
岩 㟝 琳*, 多治見 左近**, 西 村一 朗*** \\ Lin IWASAKI, Sakon TAJIMI and Ichiro NISHIMURA
}

\begin{abstract}
Prefabricated housing plays a important part in the market for newly built detached housing. In this study, We have carried out a survey of prefabricated owner occupied detached houses. We attempted to present the position played by prefabricated housing in relation to the total housing market. This paper reveals the characteristics of purchasers of prefabricated detached houses who scrap their old house and rebuilt a new house on the same site. The main results are as follows: 1) The rebuilding ratio of prefabricated detached housing is roughly at the same level as for the total newly built detached owned housing market. 2) Prefabricated rebuilt houses, on average, are larger and more expensive than newly built traditional timber constructed houses. 3) In general, scrap and build house purchasers, relative to first time buyers tend to be older. And they tend to have higher incomes and private funds so homes purchased tend to be of higher quality, have a larger floor space, and are more expensive. 4) As for the motivation for scrapping and rebuilding the extent of dilapidation and cramped size of the previous house are the primary reasons. Another important reason is to build a house specially designed to have two married generations under the same roof.
\end{abstract}

Keywords: Newly Built, Prefabricated Housing, Detached Owned House, Rebuilt, Housing Scale, Purchaser Attributes 新設着工, プレハブ住宅, 戸建持家, 建替, 住宅規模, 購入者属性

\section{1．背景と目的}

2004 年の新設住宅着工戸数は前年比 $2.5 \%$ 增の 118 万 9,049 戸 で、 2 年連続の增加となった。利用関係別では、持家は同 $0.8 \%$ 減の 36 万 9,852 戸であるが、プレハブ持家は同約 $0.4 \%$ 増の 66,224 戸で持家全体の約 $18 \%$ を占めている文1)。

プレハブ住宅は、1950 年代に住宅市場に登場して約半世紀 の時が経過した。住宅市場では新設した持家住宅の約 2 割近く を占めてきているが、この数字以上に、生活様式、住宅部品、 住宅価格等、様々な面で大きな影響力を持つ存在になってい る。また、在来工法等による木造等の住宅が、全国約数万社と 言われる工務店や建設会社からの供給であるのに対し、プレ ハブ住宅はせいぜい十数社からの供給であり、プレハブ住宅 メ一カー各社の供給方法や活動は新設着工住宅市場のみなら ず住宅ストックの形成に於いても重要な役割を果たしている と言える。とは言うものの、現状、プレハブ住宅が住宅市場の 中で如何なる役割を持ち、如何なる特徴を持っているかにつ いては必ずしも明らかにされていない。プレハブ住宅に関す る既往の研究でも、生産システム文2) や価格文3)、住宅性能文4) 等 の蓄積はあるが、住宅市場におけるプレハブ住宅の役割を明 らかにするためには、建設したプレハブ住宅の購入されてい る現状に的を絞り、幅広くその需要実態を捉えた調查・研究が 必要と思われる。
一方、プレハブ住宅に限らないが、住宅供給側にとって、戸 建持家住宅の建替需要層は最良の顧客である。住宅一次取得 層に比べ、既に土地を所有しているため、住宅に投資を集中で き、建築費も高額になる傾向にあるからである。また、毎年の 新設着工に伴う住宅戸数の蓄積により住宅ストックが增大し ている現在において、建替は住宅需要の市場動向に影響を与 える要素のーつに挙げられる。

これまでの研究において、プレハブ戸建持家住宅を対象に、 住宅の規模や購入者の特性を調查・分析し、新設着工戸建住宅

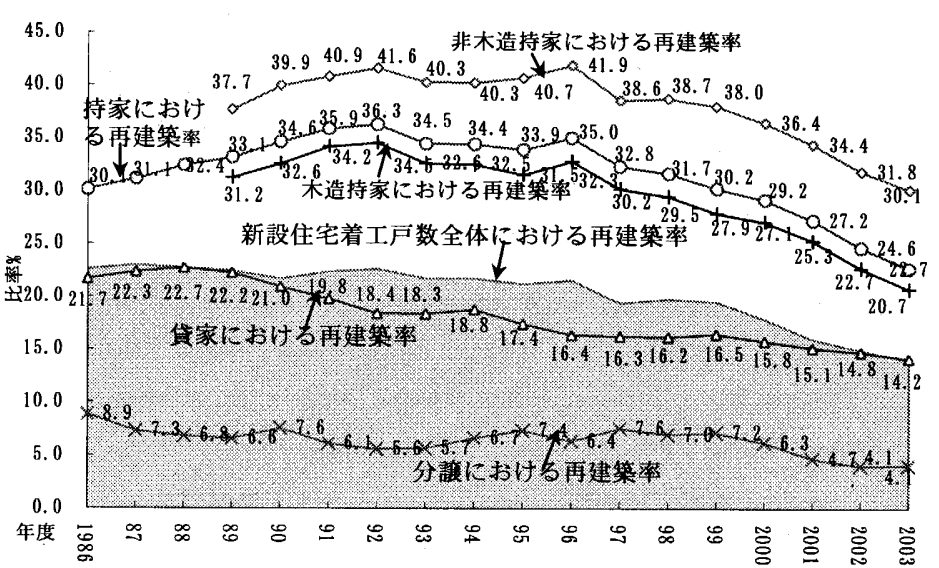

図 1. 新設住宅着工戸数における構造別利用関係別再建築率の推移
* 奈良女子大学大学院人間文化研究科 大学院生. 家修

**大阪市立大学大学院生活科学研究科 教授・工博

*** 奈良女子大学 名誉教授, 平安女学院大学 教授・工博
Graduate Student, Graduate School of Nara Women's Univ., M. Home Eco. Prof., Osaka City University Graduate School, Dr. Eng.

Emeritus Prof., Nara Women's Univ., Prof., Heian Jogakuin Univ., Dr. Eng. 
市場におけるプレハブ住宅の役割とその需要の特徴を明らかに してきた汭 7)。本稿では、プレハブ戸建持家建替住宅に着目し、 その建替率の動向及び建替えた住宅とその購入者の特性を明ら かにすることを研究の目的としている。

市場動向を示す住宅着工統計等では、直接に建替戸数を示す 統計分類はないが、「既存の住宅を除去し、引続き当該敷地内 において住宅を着工する」ものについては、別に、国土交通省 から、図 1 に示す再建築と定義した住宅の戸数が公表されてい る。この公表を始めた 1986 年度から 2003 年度までの新設住宅 着工戸数に占める再建築率の推移を見ると、ピーク時の1987 年度の $23.0 \%$ から年ごとに減少の傾向を辿り、2003 年度は $15.0 \%$ で推移している。利用関係別では、持家の再建築率が貸 家や分䛊に比べ顕著に高い。更に、1989 年度から公表し始め た構造別では、非木造による持家の再建築率が高くなっている (図 1 ）迆)。新設住宅着工戸数における持家の非木造住宅のう ち、約 7 割（2003 年度実績）がプレハブ住宅である注1)女9)こと から、再建築においてもプレハブ戸建住宅が主要な比率を占め ていると言える。しかし、現状の統計には、木造やプレハブ住宅等 を対象にした新設市場における構造別における工法別等の再建築 (以下では建替と称す)の戸数や住宅規模等に関しては明らかにされ ていない。

また、戸建建替に関する既往の研究おいても、民間建売住宅・団 地の変容過程に焦点を当てた中での建替の研究文10)、既成市街地にお ける戸建建替住宅のケース・スタディ价、ある一定の地域の建替前 後の住宅実態の比較分析文12)等、プレハブ住宅以外の建替住宅に関す るものがあるが、いずれも対象地域が限定されており、住宅取得時 の各種要因や購買者の特性について、幅広く全国的な実態調查 に基づいて分析してはいない。

\section{2. 調㚗方法と分析対象}

本研究全般に関わるプレハブ戸建持家住宅の調查は、(社) プレハ ブ建築協会の会員であり、全国展開の販売をしているプレハブ住宅 メーカーから調查可能な 3 社に協力を求めて行なった。この 3 社の 一戸建住宅の 2003 年度の販売実績は、プレハブ戸建住宅全体の約 $25.4 \%$ 济2)占めている。調查物件は 2000 年 4 月〜 2002 年 3 月迄の 2 年間に各都道府県に於いて建築され、入居済みのプレハブ戸建住 宅を対象にした。調査方法と調查内容及びその件数は表 1 に示す。回 収件数の 13,177 件に対し、注文住宅に占める建替、住替、一次取得 の切口における有効件数は 10,856 件である (以外は建売等)。調査 結果の地域区分、取得区分別の有効件数を表 2 に示す。これより抽 出した建替の情報が本稿の分析対象である。

尚、本稿では新設着工におけるプレハブ戸建持家建替住宅の規模 やその購入者の特性を明確にするため、注文住宅のマイホームを初 めて購入する一次取得層の特性を対比させた。

\section{3. 分析轺果と考察}

\section{1 定轱}

本研究対象のプレハブ住宅は、部材の加工・組立を工場で行い、建 築現場で所定の位置に取り付ける工法がシステム化されている住宅 を意味する。生産性の向上、品質の均一性、精度の向上などを
ねらった建築生産の技術革新によって生産したもので、量産 品もあれば、一品生産のものもある好)。また、本稿での建替 層は既存の戸建持家住宅を除去し、引き続きその敷地内に新 しい戸建持家住宅を建設する購入者（住宅二次取得層）を意味 する。比較対象の一次取得層は、従前の住宅（公営・民営を含 む借家や社宅、官舎等）から出て、建売住宅を除き、初めて注 文住宅のマイホームを取得する購入者である。

\section{2 新設着工持家と本調査のプレハブ戸建持家住宅の建替率}

実態調查に基づく分析結果から、プレハブ戸建持家住宅の全国平均 的な建替率は $26.5 \%$ である。図 1 に示した新設着工持家住宅におけ る再建築率の同期間の平均比率 $28.3 \%$ に近い值が得られており、本 実態調查の結果も市場全体の数值を反映していると言える。これを 地域別に比較してみると、三大都市圈におけるプレハブ戸建持家の 建替率が国土交通省の公表した持家の再建築率に近いレベルにある。 関東におけるプレハブ戸建持家の建替率が顕著に高いことが明らか になった。東北のプレハブ戸建持家の建替率が同新設持家の再建築 率を大きく下回り、四国ではそれを上回っている（表 2)。

\section{3 建替後の住宅特倒}

\subsection{1 数地面糟と延床面稳}

一般的に、住宅の敷地面積は、敷地条件・建築条件と並び、建築 した住宅の規模に大きく影響する。表 3 の建替層の敷地と住宅の延 床面積を一次取得層の上位 3 迄の面積帯で比較してみると、建替層 の住宅の 1 棟当たり敷地面積「140〜 $260 \mathrm{~m}^{2}$ 未満」は $42.5 \%$ 、一 次取得層では $63.2 \%$ を占める。「 $260 \mathrm{~m}^{2}$ 以上」は一次の $27.8 \%$ を大き く上回る $35.8 \%$ であるが、「140 $\mathrm{m}^{2}$ 末満」の狭小敷地も、一次 取得の $9.0 \%$ を上回る $21.7 \%$ である。これらの敷地面積の傾向

表 1 . 調查期間、方法と内容及び回収状況

\begin{tabular}{|c|c|c|}
\hline \multicolumn{2}{|c|}{ 項 目 } & 内 \\
\hline \multicolumn{2}{|c|}{ 調查期間 } & 2002 年 4 月 25 日～ 7月 25 日 \\
\hline \multicolumn{2}{|c|}{ 調査方法 } & $\begin{array}{l}\text { 電子メールを用い、調査項目を示した書式を空口担当者に } \\
\text { 送付し、先方から記入結果を受ける } \\
\end{array}$ \\
\hline \multirow{4}{*}{$\begin{array}{c}\text { 調 } \\
\text { 查 } \\
\text { 項 } \\
\text { 目 }\end{array}$} & 住 宅 & $\begin{array}{l}\text { 建設地、敷地面積、延床面積、階数、建築費、坪単価、敷 } \\
\text { 地間口、前面道路幅員、従前住宅の築年数 }\end{array}$ \\
\hline & 建築条件 & 用途地域、建ぺい率、容積率、高度地区、防火指定 \\
\hline & 購入者 & $\begin{array}{l}\text { 年齢、家族人数、家族構成、従前の住宅状況、建築動機、 } \\
\text { 職業、年收、契約形態、購入動機 }\end{array}$ \\
\hline & 資金計画 & 自己資金額、贈与有無、借入金額、借入先、土地用意有無 \\
\hline \multirow{3}{*}{\begin{tabular}{|l|} 
回 \\
収 \\
数 \\
\end{tabular}} & A社 & $5,994$ 件 (全件比 $45.5 \%)$ \\
\hline & B社 & 4,997件(同 $37.9 \%)$ \\
\hline & C社 & $2,186$ 件 (同 $16.6 \%)$ \\
\hline
\end{tabular}

表 2. 地域区分及び地域別新設着工持家再建築率と本調査研究 の取得区分状況（単位：\%)

\begin{tabular}{|c|c|c|c|c|c|c|}
\hline \multirow[b]{2}{*}{ 地域 } & \multirow[b]{2}{*}{ 地域の内訳（都道府県） } & \multirow{2}{*}{$\begin{array}{l}\text { 新設着工戸建 } \\
\text { 持家における } \\
\text { 再建筑率* }\end{array}$} & \multicolumn{4}{|c|}{ 実態調査の有効回答 } \\
\hline & & & 件数 & \begin{tabular}{|c|} 
建替 \\
$\mathrm{N}=2874$ \\
\end{tabular} & \begin{tabular}{|c|} 
住替 \\
$\mathrm{N}=1083$ \\
\end{tabular} & $\begin{array}{c}\text { 次取得 } \\
\mathrm{N}=6899\end{array}$ \\
\hline 北海道 & 北海道 & 17.0 & $\mathrm{~N}=1.22$ & 16.7 & 10.9 & 724 \\
\hline 東北 & $\begin{array}{l}\text { 青森、岩手、宮城、秋田、山 } \\
\text { 形、福岛 }\end{array}$ & 34.6 & $N=565$ & 18. 9 & 8.3 & 72.7 \\
\hline 関東 & 荻城、杤木、群馬、埼玉、千 & 32.2 & $\mathrm{~N}=2716$ & 37.2 & 10.7 & 52.2 \\
\hline 北陸 & 新渴、䈏山，石川，福井 & 29.4 & $\mathrm{~N}=482$ & 23.9 & 8.5 & 67.6 \\
\hline 中部 & $\begin{array}{l}\text { 山梨、長野、岐阜、静岡、愛 } \\
\text { 三重 }\end{array}$ & 27.0 & $\mathrm{~N}=2251$ & 25.8 & 7.0 & 67.3 \\
\hline 近幾 & $\begin{array}{l}\text { 溼賀、京都、大阪、兵庫、奈 } \\
\text { 良、和山歌出 }\end{array}$ & 28.8 & $\mathrm{~N}=2203$ & 26.5 & 14.5 & 59.0 \\
\hline 中国 & 鳥取、苴根、岡山、㢆島、山口 & 22.1 & $\mathrm{~N}=984$ & 16.6 & 8.6 & 74.8 \\
\hline 四国 & 德島。香仪，媛。高知 & 24,0 & $N=363$ & 28.4 & 8.0 & 63.6 \\
\hline 九州 & 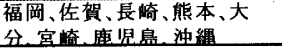 & 21.6 & $\mathrm{~N}=1100$ & 16.5 & 8.5 & 75.1 \\
\hline & 全 国 & 28.3 & $\mathrm{~N}=10856$ & 26.5 & 10.0 & 63.6 \\
\hline
\end{tabular}


は既存敷地の状況を反映していると言える。建替住宅は全件 が自由設計であるため、プレハブ住宅も敷地対応力を有して いると言える。また、住宅の規模を示す建替層の延床面積は $\left\lceil 100 \sim 160 \mathrm{~m}^{2}\right.$ 未満」が $55.5 \%$ で、一次取得層の $83.0 \%$ を大きく 下回り、これより広い面積帯ほど建替層の比率が高くなって いる（表 3)。

全国の平均敷地面積は、一次取得の $266.3 \mathrm{~m}^{2} に$ 対し、建替は $282.1 \mathrm{~m}^{2}$ である。地域別では建替が東北、北海道、四国の順に 広いのに対し、一次取得は九州、四国、北海道の順になる。近 畿は建替と一次取得両者において最小数地面積を呈している。 また、全国の平均延床面積は一次取得の $136.5 \mathrm{~m}$ に対し、建替 は154.4 m²゙ある。建替における各地域の延床面積は一次取得 のそれを上回るものが多い。近畿と関東の敷地面積と延床面 積は全国平均を下回るが、実質容積率が他地域を大きく上 回っている（図 2 )。

尚、上述したように、建替住宅は一次取得の住宅に比べ、敷 地面積が $140 \mathrm{~m}^{2}$ 未満の狭小敷地の占める比率が大きく上昇し、 プラン提案における設計の自由度が高くなっていることを示 しており、これらは建替に対してプレハブ住宅を位置づける 特徴と言える。

\section{3 .2 建䈎費}

本稿での建築費は、土地価格と外構費を除く上物のみの税別 価格である。全国の 1 棟当たり建築費を価格帯別に見ると、 「2500万円未満」が、一次の $83.2 \%$ に対し、建替は $54.5 \%$ を占 める。建替では「2500〜3500万円未満」が $33.9 \%$ 、「3500万 円以上」が $11.7 \%$ で、高価格帯になるほど一次取得層の比率 を大きく上回っている。既存住宅の解体費、新設住宅の内・外 装・設備機器等の仕様グレード設定の違いも影響するが、建替 層の住宅延床面積が一次より広いことに比例して、建築費も 高い結果を示している。

建替の地域別 1 棟当り建築費を比較してみると、「2 500 万円 未満」は九州が最多の $71.8 \%$ 、次いで近畿 $61.3 \%$ 、中国 $58.9 \%$ 、 四国と北海道 $56.3 \%$ の順になる。一方、「2500 万円以上」では、 東北の $58.0 \%$ に続き、中部 $53.7 \%$ 、北陸 $52.2 \%$ 、関東 $46.8 \%$ の順 である（図 3 ）。全般的にみると、東日本の建替建築費が高く、 西日本は建築費が低い。これは 2500 万円を境とする一次取得 層の構成比が地域的な格差が少ない点とは对照的な結果にな
る。建替では一般に価格帯が多様化していると言える。

建替住宅 1 棟当りの全国平均建築費は、一次取得の 2,157 万 円に対し、2，608 万円である。東北が最高額の 2,719 万円、九

表 3．建替層の住宅敷地面積と延床面積（単位：\%）
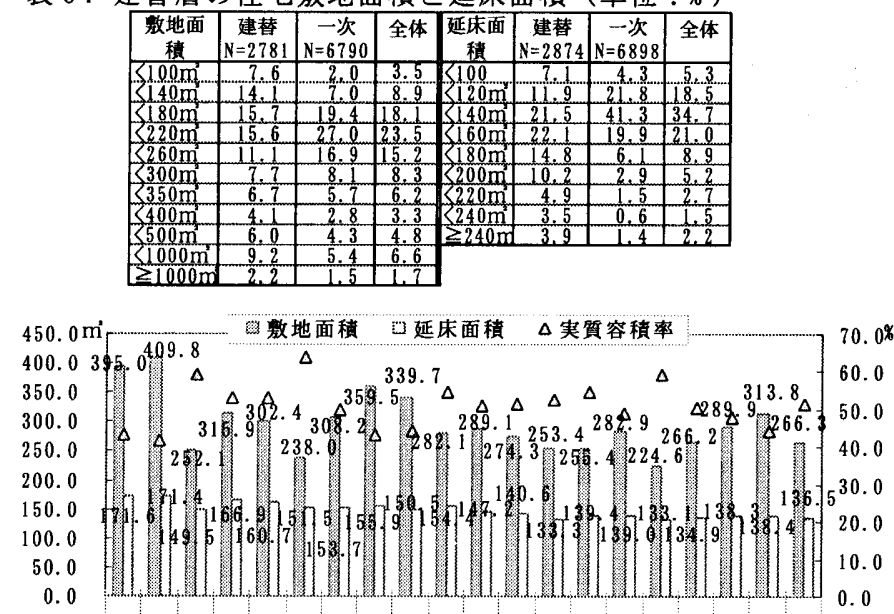

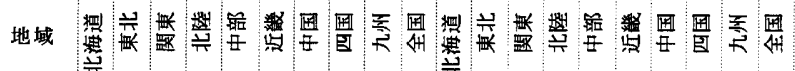

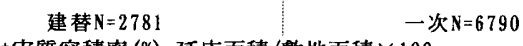

*実質容櫴察 $(\%)=$ 延床面積 $/$ 数地面積 $\times 100$

図 2. 地域別平均敷地面積之延床面積

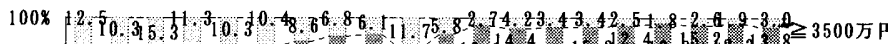

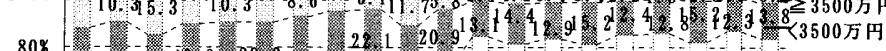

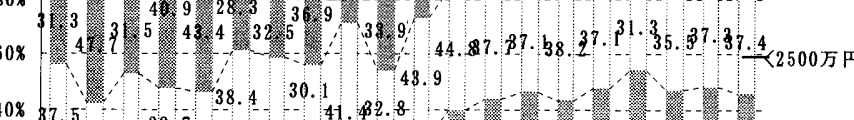

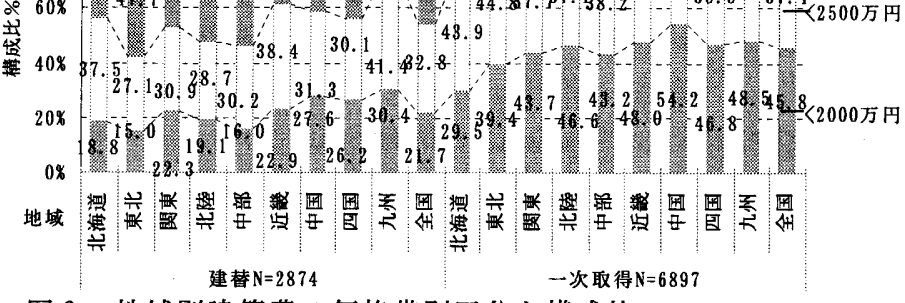

図 3 . 地域別建築費の価格帯別区分と構成比

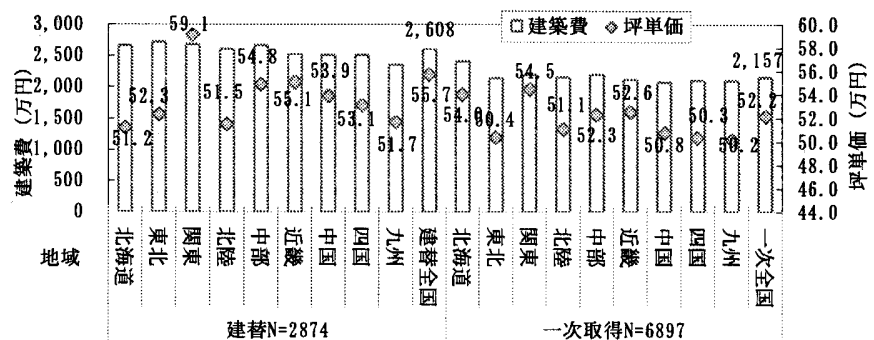

図 4. 地域別 1 棟当り平均建築費と平均坪単価

表 4.プレハブ戸建持家建替住宅と新設住宅着工市場における木造、鉄骨造住宅の住宅規模と建築費の比較 *

\begin{tabular}{|c|c|c|c|c|c|c|c|c|c|c|c|c|c|c|c|c|c|c|}
\hline \multirow[b]{3}{*}{ 地域 } & \multicolumn{7}{|c|}{1 棟当たり住宅延床面積 $\left(\mathrm{m}^{2}\right) \mathrm{A}$} & \multicolumn{7}{|c|}{1 棟当たり住宅建筑費（万円） B } & \multicolumn{4}{|c|}{ 坪単価 (万円) $\Sigma=B / A * 3.3$} \\
\hline & \multicolumn{6}{|c|}{ 新設着工居住専用建築物 (2000～01年度) } & \multirow{2}{*}{\begin{tabular}{|l|} 
実態調查 \\
プレハ \\
ブ建替 \\
$\mathrm{N}=2874$ \\
\end{tabular}} & \multicolumn{6}{|c|}{ 新設着工居住専用建築物 (2000 01年度) } & \multirow{2}{*}{\begin{tabular}{|l|} 
実懸調査 \\
プレハ \\
ブ建替 \\
$\mathrm{N}=2874$
\end{tabular}} & \multicolumn{3}{|c|}{ 新設着工市場 } & \multirow{2}{*}{\begin{tabular}{|l} 
実態調查 \\
プレハ \\
ブ建替
\end{tabular}} \\
\hline & $\begin{array}{l}\text { 全体 } \\
\mathrm{N}=1282 \\
247\end{array}$ & $\begin{array}{l}\text { 標淮偏 } \\
\text { 差 }\end{array}$ & $\begin{array}{l}\text { 木造 } \\
\mathrm{N}=9910 \\
44\end{array}$ & $\begin{array}{l}\text { 標準 } \\
\text { 偏差 }\end{array}$ & $\begin{array}{l}\text { 鉄骨造 } \\
\mathrm{N}=2366 \\
55\end{array}$ & $\begin{array}{l}\text { 標準偏 } \\
\text { 差 }\end{array}$ & & $\begin{array}{l}\text { 全体 } \\
\mathrm{N}=128 \\
2247 \\
\end{array}$ & $\begin{array}{l}\text { 標準偏 } \\
\text { 差 }\end{array}$ & $\begin{array}{l}\text { 木造 } \\
\mathrm{N}=991 \\
044 \\
\end{array}$ & $\begin{array}{l}\text { 標淮偏 } \\
\text { 差 }\end{array}$ & $\begin{array}{l}\text { 鉄骨造 } \\
\mathrm{N}=2366 \\
55\end{array}$ & $\begin{array}{l}\text { 標準偏 } \\
\text { 差 }\end{array}$ & & 体 & 木造 & 鉄骨 & \\
\hline 北海道 & 192.2 & 13.5 & 145.4 & 1.7 & 191.7 & 5.9 & 171.6 & 2757 & 10.5 & 2094 & 17.5 & 2788 & 41.7 & 2665 & 47.3 & 47.5 & 48.0 & 51.3 \\
\hline 東北 & 147.8 & 11.8 & 131.3 & 7.2 & 174.0 & 23.3 & 171.4 & 2115 & 218.9 & 1845 & 113.4 & 2685 & 359.9 & 2719 & 47.2 & 46.4 & 50.9 & 52.3 \\
\hline 閔東 & 172.5 & 39.5 & 118.6 & 8.3 & 173.0 & 12.2 & 9.5 & 2889 & 862.8 & 1945 & 48.1 & 3088 & 482.2 & 2676 & 55.3 & 54.1 & 58.9 & 59.1 \\
\hline 北陸 & 153.9 & 12.1 & 135.2 & 5.7 & 186.6 & 35.3 & 166.9 & 2365 & 201.9 & 2078 & 106.1 & 2788 & 571.5 & 2605 & 50.7 & 50.7 & 49.3 & 51.5 \\
\hline 中部 & 157.5 & 17.1 & 128.8 & 3.0 & 165.6 & 8.8 & 160.7 & 2531 & 231.9 & 2099 & 46.0 & 2693 & 169.8 & 2670 & 53.0 & 53.8 & 53.7 & 54.8 \\
\hline 近畿 & 170.1 & 23.5 & 118.5 & 7.0 & 162.0 & 5.1 & 151.5 & 2793 & 373.2 & 1986 & 103.9 & 2823 & 138.3 & 2529 & 54.2 & 55.3 & 57.5 & 55.1 \\
\hline 中国 & 160.6 & 13.5 & 124.8 & 6.3 & 168.3 & 15.1 & 153.7 & 2546 & 182.2 & 1967 & 97.9 & 2737 & 239.7 & 2510 & 52.3 & 52.0 & 53.7 & 53.9 \\
\hline 四国 & 167.4 & 16.8 & 131.2 & 6.8 & 184.5 & 11.0 & 155.9 & 2518 & 137.2 & 1973 & 101.5 & 2785 & 19 & 08 & 49.6 & 49.6 & 49.8 & 53.1 \\
\hline 九州 & 180.3 & 34.0 & 125.2 & 6.5 & 163.6 & 13.6 & 150.5 & 2578 & 532.6 & 1830 & 182.1 & 2446 & 250.7 & 2357 & 47.2 & 48.2 & 49.3 & 51.7 \\
\hline 全国 & 165.3 & 25.8 & 126.4 & 8.8 & 171.4 & 18.1 & 154.4 & 2563 & 488.2 & 1960 & 139.4 & 2755 & 362.2 & 2608 & 51.2 & 51.2 & 53.0 & 55.7 \\
\hline
\end{tabular}

*1) 国土交通省「建築統計年報」より算出したもので、建筑費は予定額である。

2）新設の全体は、木造、鉄骨鉄筋コンクリート造、鉄筋コンクリート造、鉄骨造、コンクリートブロック造、その他を含む。

3) 新設居住専用建築物の階数別内訳は、木造 1 ～3階建 $100 \%$ 、鉄骨造同 $98.5 \%$ と階建以上 $1.5 \%$ 、全体同 $98.2 \%$ と 4 階建以上 $1.8 \%$ である。

4) 実態調查の分析対象は鉄骨造 $97.7 \%$ 、木造2.3\%で、1 3階建が100\%である。 
州は最低額の $2 ， 357$ 万円である。両者の延床面積の差が約 21 $\mathrm{m}^{2}$ に対し、建築費は約 362 万円の開きが生じている。三大都市 圈別では、関東、中部、近畿の順であり、近畿は全国平均を下 回っている。延床面積に対する坪単価は、一次取得と同様に関 東が最高で、九州が最低である(図 4)。

\section{3 .3 新設住宅市場における本謂查研究の位置づけ}

上記の結果を踏まえ、本研究の調査・分析対象と同様な着工 時期の国土交通省の住宅着工統計の情報を用い、表 4 . 宅市場における他種別住宅とプレハブ戸建持家の住宅規模と建 築費を比較した在 3 )。比較対象として、居住専用建築物生4)の全 体と構造別の木造、鉄骨造住宅の都道府県別の情報を抽出し、 表 2 と同様な地域区分を行った。

プレハブ建替住宅の特徵を他種別住宅と比較してみると、1 棟当たり平均住宅延床面積では、プレハブ建替は木造の126.4 $\mathrm{m}^{2}$ を約 $28.0 \mathrm{~m}^{2}$ ぼ゙上回るが、新設全体の $165.3 \mathrm{~m}^{2} 、$ 鉄骨造の $171.4 \mathrm{~m}^{2}$ より下回った。但し、4 階建以上を含む新設着工居住 専用建築物の全体とそのなかの鉄骨造は、戸建持家のみの住宅 の傾向を適切に反映できない可能性があるため、本調査対象之 階数が同様（全件が $1 \sim 3$ 階建）の木造住宅との比較を行なっ た。延床面積の地域別では、木造はプレハブ建替と同様に、北 海道が最も広く、三大都市圏が狭い傾向にある。木造の最多面 積の北海道と最少面積の近畿の差が $26.9 \mathrm{~m}^{2}$ で、プレハブ建替 の同北海道と近畿の差も $20.1 \mathrm{~m}^{2}$ 呈している。

また、 1 棟当たり平均住宅建築費は、プレハブ建替では木造 の1，960 万円を約 648 万円上回っている。木造はプレハブの一 次取得の建築費 2,157 万円と比較しても下回っている。住宅建 築費は住宅仕様のグレードや床面積の広さに大きく関連する が、建築費の坪単価では、一般に延床面積が狭いほど高く、逆 に広いほど建築コストの低減に粨がることから安くなる。それ ぞれの延床面積に対する坪当たり平均建築費を比較してみる と、プレハブ建替は比較対象の木造住宅よりやや高くなる傾向 にある。三大都市圈の坪単価が高くなる傾向は両者同じである (表 4)。

上記分析結果から、プレハブ戸建持家建替住宅は、新設着工 木造居住専用住宅だけでなく、プレハブ戸建持家の一次取得の 住宅に対しても延床面積が広く、建築費が高額になる傾向が見 られる。これはプレハブ戸建持家における建替住宅の特性と言 える。

\section{4 建替層の社会的・経済的屈性}

\subsection{1 社会的風性}

建替層の住宅購入者である世帯主の全国平均年齢は 49.1 肯 で、一次取得層の 37.3 歳を大きく上回る。建替率の高い関東、 近畿、四国の平均年齢が全国平均を上回るが、建替率の低い北 海道も関東に次ぐ高年齢である。地域別年齢構成では、北海 道、関東、近畿の「50 歳代以上」の比率が顕著に高く、平均年 齢の最も若い中部のそれは最も低い。また、購入者年齢層別の 特徴を見ると、1 60 歳未満」では各階層とも後述する年収が一 次取得より少ない。しかし、住宅の延床面積と建築費は各階㕍 とも一次取得より高い傾向にある。そのなかで、「45 歳〜 50 歳
未満」の年踰層が最高額建築費で最も広い延床面積の住宅を購 入している（表 5 ）。建替住宅の広さは後述する二世帯同居によ る影響も大きいと言える。

建替層の世帯主職業は、会社員が最多の $56.3 \%$ （内訳は上場 企業 $25.7 \%$ 、非上場企業 $30.6 \%$ ）である。一次取得層に比べ、上 場企業の会社員比率が低く、一方、自営業や定年退職等による 無職の比率が高い（表 6 ）。地域別では、北海道、九州の会社員 比率が低く、自営業や公務員が高い比率を占める。会社員比率 の高い中部、中国は逆の傾向にある。三大都市圈では、近畿、 関東の自営業や無職の比率が他地域に比べ高い。職業別に見る 建替層の特徵では、一次取得に比べ各職業とも年長で、住宅規 模も広く、建築費も相応して高い傾向にある。

家族構成は住宅購入に当たり、間取り構成への影響が大き く、住宅規模の特徴にも最も影響する要因の一つである。建替 首の家族構成は、一次取得に比べ、核家族比率が $42.9 \%$ で一次 取得の $75.1 \%$ を大きく下回り、同時に、核家族の内訳の構成比 も大きく異なっている。「夫婦十子供は乳幼児期や学齢期」の 比率が低く、「夫婦 +子供は社会人」の占める比率が高い。単 身世帯やその他世帯の構成比は一次取得との開きは少ないが、 二世帯同居は顕著に高くなっている。地域別では、中部、東北、 北陸の順で二世帯同居率がいずれも $45 \%$ 前後で最も高く、北海 道が最も低い $28.1 \%$ である（図 5)。この地域の特性は、国土交

表 5 . 建替層の年秢層別構成比と主要特性（単位: \%, 万円, $\mathrm{m}^{2}$ )

\begin{tabular}{|c|c|c|c|c|c|c|c|c|}
\hline \multirow{2}{*}{\begin{tabular}{|c|} 
年齢 \\
層 \\
\end{tabular}} & \multicolumn{4}{|c|}{ 建替 $\mathrm{N}=2214$} & \multicolumn{4}{|c|}{ 一次N $=5772$} \\
\hline & 成比 & 年収 & 延床面皘 & 建築費 & 構成比 & 年収 & 延床面積 & 建築費 \\
\hline$\langle 30$ 歳 & 5.6 & 417 & & 2,454 & 17.3 & 450 & 130.2 & 2,006 \\
\hline & & & & & 29.9 & 54 & & \\
\hline & & 62 & & 2,557 & 23.1 & 646 & .6 & 2,1 \\
\hline & 11.4 & 70 & & 2,546 & 12.4 & 742 & 138.6 & 2,204 \\
\hline & 9.7 & 759 & 161.8 & 2,706 & 6.2 & 786 & 45.5 & 2,308 \\
\hline & 16.6 & 780 & & 2,562 & 1.2 & 826 & & 2,297 \\
\hline & & 76 & & & 1 & 829 & & 2,251 \\
\hline & & 679 & & & 2.0 & 649 & & 2,394 \\
\hline 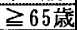 & 1.2 & 484 & 149.2 & 2,663 & 1.9 & 451 & 147.8 & 2,468 \\
\hline
\end{tabular}

表 6. 建替層の職業別構成比と主要特性（単位: \%, 万円， $\mathrm{m}^{2}$ )

\begin{tabular}{|c|c|c|c|c|c|c|c|c|c|c|}
\hline \multirow{2}{*}{ 職 業 } & \multicolumn{5}{|c|}{ 建替 $\mathrm{N}=2131$} & \multicolumn{5}{|c|}{ 一次取得 $N=5693$} \\
\hline & 構成比 & 年齢 & 年収 & 逐床面程 & 建嶨費 & 構成比 & 年践 & 年収 & 正床面積 & 建築 \\
\hline 会社員 (上場) & 25.7 & 45.5 & 741 & 151.2 & 2540 & 34.6 & 36.0 & 652 & 134.9 & 2115 \\
\hline 会社員 (非上場) & 30.6 & 44.4 & 596 & 152.7 & 2499 & 33.5 & 34.9 & 512 & 131.9 & 2038 \\
\hline 公務筫 & 13.0 & 47.4 & 789 & 155.0 & 2593 & 15.9 & 37.3 & 656 & 137.6 & 2146 \\
\hline 教職貝 & 3.3 & 47.8 & 837 & 158.9 & 2706 & 4.0 & 39.0 & 702 & 148.1 & 2339 \\
\hline 自営業 & 10.3 & 53.4 & 578 & 164.6 & 2766 & 5.9 & 41.1 & 625 & 147.6 & 2345 \\
\hline 自由業 & 1.2 & 54.6 & 566 & 174.9 & 3125 & 0.8 & 39.8 & 509 & 144.4 & 2433 \\
\hline 矨師 & 0.8 & 46.7 & 1010 & 220.7 & 4794 & 1.7 & 39.6 & 1347 & 184.9 & 3372 \\
\hline 会社・团体役員 & 2.4 & 56.6 & 1040 & 167.3 & 2995 & 1.3 & 44.6 & 940 & 158.6 & 2709 \\
\hline 無䠽 & 12.7 & 63.9 & 264 & 142.6 & 2381 & 2.4 & 61.7 & 292 & 136.1 & 2232 \\
\hline
\end{tabular}

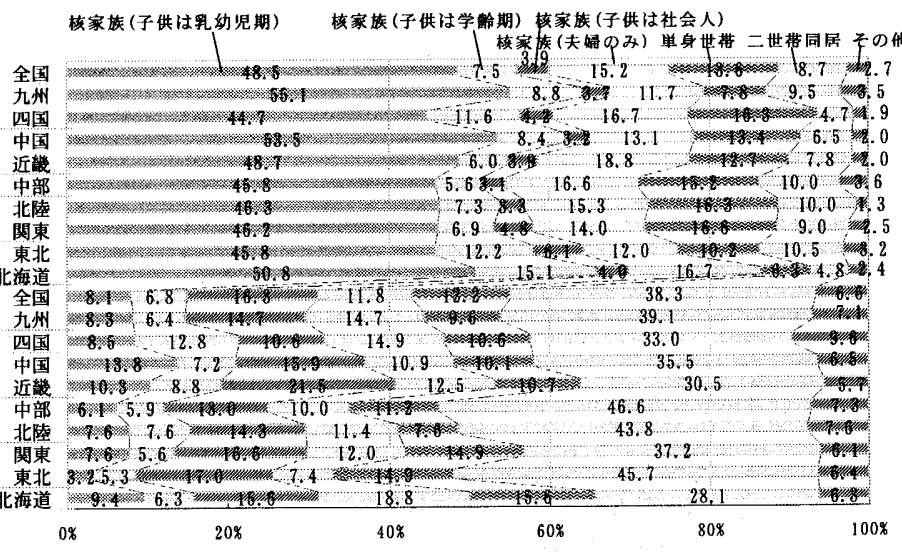

図 5.建替層の地域別家族形態 
通省の平成 15 年住宅需要実態調查の結果においても、地域別 多世帯同居率に同様な傾向が見られた注5)文14)。また、本稿では、 平均年齢の若い地域に二世帯同居率が高く、平均年龄が年長 の地域に二世帯同居率が低い傾向が見られる(表 7 )。

建替層の家族形態別特徵では、「子供は社会人」の比率が高 くなる核家族は平均年齢が他に比心゙最も高くなるが、平均延 床面積と 1 棟当たり平均建築費は単身世帯に次いで少ない。 一方、二世帯同居は世帯主の若年齢にも拘わらず、年収は核家 族に次いで多く、平均延床面積も広く、建築費も最高額である (表 8)。

\subsection{2 経済的属性}

\subsubsection{1 年収と住宅建築費の年収倍率}

建替層の世帯主本人の全国平均年収は 658 万円で、一次取得 層の平均 613 万円とそれ程大きな開きが無い。地域別では北海 道、関東、近畿の順で全国平均を上回る高額年収である。これ らの地域では平均年齢も高い。建替層年収区分別では、低所得 の「400万円未満」の比率は全国平均 $12.4 \%$ で、一次取得の $11.6 \%$ を上回る。これは建替層が年長で定年退職の比率が高いこと に関連していると考えられる。地域別では四国が $24.6 \%$ に達 し、北海道が 0\%である。一方、「400〜800万円未満」は一次 取得の $69.9 \%$ より少ない $54.7 \%$ であり、以降高額年収ほど建替 の占める比率が高くなる。年収区分別建替層の特徵では、低所 得の「400 万円未満」を除き、年収が增加寸るにつれ、年齢も 増え、また高年収ほど住宅規模も建築費も上がる傾向にある (表 9)。

建替層の地域別住宅建築費を年収倍率注6)で見ると: 全国平 均は 4.0 倍である。地域別では、北陸が最高の 4.5 倍、四国が 4.4 倍、東北、中部、中国が同レベルの 4.3 倍である。一方、 平均年龄が高く、高額年収の北海道が最低倍率の 3.4 倍であ り、近畿が 3.6 倍、関東、九州が 3.8 倍になる。全国新設市場 の工法を問わない注文住宅を購入する住宅取得費の平均年収 倍率は、4.4 倍注》义15)であり、プレハブ持家建替層の住宅取得 費の平均年収倍率はそれより低いレベルにあることが明らか になった。

\subsubsection{2 資金計画}

建替層の自己資金額区分では、「500万円未満」が一次取得 の $66.8 \%$ に対し、全件の $34.5 \%$ を占め、「500〜 1000 万円未満」 では両者に差がなく約 $11.0 \%$ 、「1000万円以上」の高額帯では 建替層の占める比率が高くなる。一方、借入金額区分では、 $「 1500$ 万円」を境目に、高額になるほど、一次取得の借入比率 が高く、建替では低くなる傾向にある。建替層の全国平均自己 資金は一次取得の 636 万円を大きく上回る 1，399 万円（建築費 の 53.6\%) で、借入金は一次の同 1,630万円を下回る 1, 338 万円 （同 $51.3 \%$ ) である。地域別では、平均年収が最も少ない四国が 自己資金が最多の 1,718 万円であり、続いて関東 1,505 万円、 近畿 1,496 万円の順になる。一方、平均年収の最多額の北海道 が自己資金額が最少で借入金が最多である。この相違は同地 域の二世帯同居率が他地域に比べ最も低いことにより、親世 帯からの贈与などが少なくなる影響も考えられる。

\section{4 .3 建替動機と建替前住宅の築年数}

建替層の住宅建設の動機は、一次取得層のマイホーム願望 が $67.4 \%$ の最多に対し、従前の住宅の老朽化及び狭小化が全件 最多の $62.8 \%$ で、続いて二世帯同居目的が $16.4 \%$ である（表 10 )。 地域別では、東北、関東、近畿、北陸は従前の家屋の老朽・狭 小化比率が高く、四国、中部、中国のそれが低い。逆に中部、 中国では二世帯同居率が最も高い。

建替前の住宅の経年履歴では、工法または構造別状況は不 明であるが、築年数の回答が得られたものについて、全国平均 の築年数 31.3 年に対し、四国が最長の 45.3 年、東北が最短の 26.5 年である（表 11 )。住宅の建替動機と対比した場合、従前 の住宅の狭小・老朽化率の高い地域では建替前住宅の築年数 が短く、逆に狭小・老朽化率が低い地域ではその耐久年数が長

表 7. 建替層の地域別家族形態別の世帯主平均年齢（単位：\%，歳）

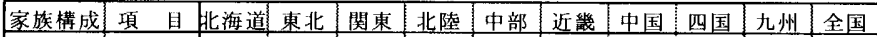

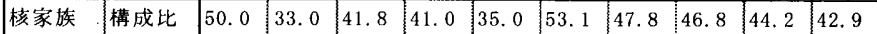
\begin{tabular}{|l|l|l|l|l|l|l|l|l|l|l|l|} 
& 平均年輠 51.8 & 54.1 & 52.9 & 48.6 & 49.5 & 51.5 & 49.1 & 51.6 & 50.3 & 51.3 \\
\hline 二世带 & 構成比 & 28.1 & 45.7 & 37.2 & 43.8 & 46.6 & 30.5 & 35.5 & 33.0 & 39.1 & 38.3 \\
\hline
\end{tabular}

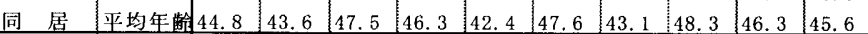

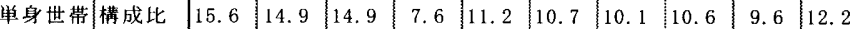
\begin{tabular}{|l|l|l|l|l|l|l|l|l|l|}
\hline 平均年船 53.0 & 52.9 & 53.8 & 43.2 & 47.4 & 48.5 & 48.8 & 47.0 & 55.9 & 51.1 \\
\hline
\end{tabular}

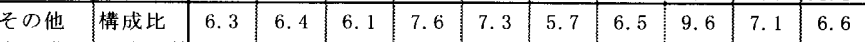

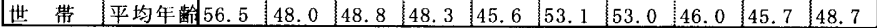

表 8、建替層の家族形態別構成比と主要特性（単位：\%，万円， $\mathrm{m}^{2}$ )

\begin{tabular}{|c|c|c|c|c|c|c|}
\hline & & $\mathrm{C}^{\mathrm{\prime}} \mathrm{N} \mathrm{N}=$ & 2385 & & 取得 & $=5857$ \\
\hline & [榗成] & & 延床面皘建築费 & 構成比 年軨 & & 吅皘建等 \\
\hline 㯴䀃 & \begin{tabular}{|ll|lll}
42 & 9 & 51 & 3 \\
38 & 3 & 45 & 6 \\
\end{tabular} & $\begin{array}{l}69.8 \\
639\end{array}$ & \begin{tabular}{|l|l|l|}
141.9 & 2380 \\
174.7 & 2910
\end{tabular} & & $\frac{615}{640}$ & 1030 \\
\hline 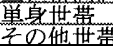 & \begin{tabular}{c|c|c}
12.2 & 51.1 \\
6.6 & 48.7
\end{tabular} & $\begin{array}{l}621 \\
565\end{array}$ & \begin{tabular}{l|l}
137 & 2319 \\
152 & 2
\end{tabular} & \begin{tabular}{c|c}
13.6 & 37.2 \\
27 & 41.2
\end{tabular} & $\frac{584}{524}$ & \begin{tabular}{c|c}
131.6 & 208 \\
139 & 6
\end{tabular} \\
\hline
\end{tabular}

表 9. 建替層の年収区分別構成比と主要特性（単位: \%, 万円， $\mathrm{m}^{2}$ )

\begin{tabular}{|c|c|c|c|c|c|c|c|c|c|c|}
\hline \multirow{2}{*}{ 世帯主年収 } & \multicolumn{5}{|c|}{ 建替 $\mathrm{N}=1739$} & \multicolumn{5}{|c|}{ 次取得 $N=5213$} \\
\hline & 構成上 & 年齢 & 年収 & 延床面和 & 煡築䕙 & 稓成 & 年歯 & 年収 & 定正床面和 & 揵筑昲 \\
\hline 100万円 & 12.4 & 46.4 & 296 & 149.8 & 2431 & 11.6 & 33.4 & 327 & 129.4 & 1955 \\
\hline لـ & 28 & 42.0 & 481 & 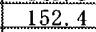 & 2477 & 41.0 & 33.2 & 486 & & 2019 \\
\hline 00万円 & & 45.4 & 660 & & 2579 & 29.0 & 37 & 662 & & 2139 \\
\hline 100 & & & 8 & & 2569 & & & 84 & & 2271 \\
\hline 20 & 9 & 53.8 & 1012 & 156.9 & 2769 & 3.9 & 46 & 102 & 15 & 2544 \\
\hline & 2. & 54 & 13 & & 2853 & 1.6 & 4 & 1234 & 4 & 2772 \\
\hline 1400 万円 & & 要 & 1739 & & 3497 & 2.0 & 43. & 1824 & 183.7 & 3413 \\
\hline 体 & 100 & 47.0 & 658 & 154.7 & 2578 & 100 & 36. & 614 & 61 & 135 \\
\hline
\end{tabular}

表 10. 住宅購入動機（単位：\%)

\begin{tabular}{|c|c|c|c|c|}
\hline 住宅購入動機 & \begin{tabular}{|c} 
建替 \\
$N=2137$
\end{tabular} & \begin{tabular}{|c|} 
一次 \\
$N=6303$
\end{tabular} & \begin{tabular}{|c|} 
住替 \\
$\mathrm{N}=950$
\end{tabular} & $\begin{array}{c}\text { 全体 } \\
\mathrm{N}=9390\end{array}$ \\
\hline 公願望 & 10.2 & 67.4 & 15.2 & \\
\hline 結婚・出産 & 1.2 & 3.8 & 0.9 & 2. \\
\hline 二世黃同居 & 16.4 & 12.5 & 16.9 & 13.8 \\
\hline ライフスタイルの変化 & 2.6 & 2.2 & 6. & \\
\hline 㐾前家屋の狭小化，老朽1 & 62.8 & 7.5 & 26.9 & 22.0 \\
\hline 環境 & 0. & 2.1 & 12.9 & 0 \\
\hline 它年・老後の生活 & $\frac{1.3}{4.9}$ & $\frac{1.2}{3.4}$ & $\frac{6.1}{14.1}$ & $\frac{1.7}{48}$ \\
\hline
\end{tabular}

表 11。建替前の住宅の築年数(単位：年，件）

\begin{tabular}{|c|c|c|c|c|c|c|c|c|c|c|}
\hline 頁目 & 北海道 & 東北 & 関東 & 北陸 & 中部 & 近幾 & 中国 & 四国 & 九 & 全国 \\
\hline 年㐘 & 27.1 & 26.5 & 29.2 & 30.1 & 30.7 & 34.3 & 39.2 & 45.3 & 39.9 & 31. \\
\hline 数 & 7 & 20 & 128 & 15 & 20 & 40 & 13 & 6 & 14 & 26 \\
\hline 隻作 & 4.7 & 8.3 & 8.5 & 7.9 & 18.2 & 1.6 & .3 & 2 & & \\
\hline
\end{tabular}

表 12. 建替層の住宅と購入者の平均像 (単位 : 歳, 万円, $\mathrm{m}^{2}$ )

\begin{tabular}{|c|c|c|c|c|c|c|c|}
\hline 地域 & $\begin{array}{l}\text { 年齢 } \\
\text { (歳) N } \\
=2214 \\
\end{array}$ & $\begin{array}{c}\text { 年収 (万 } \\
\text { 円) } \mathrm{N}=17 \\
20\end{array}$ & $\begin{array}{c}\text { 自己資 } \\
\text { 金 } \\
\text { 円) } \mathrm{N}=28 \\
73 \\
\end{array}$ & $\begin{array}{l}\text { 借入金 } \\
(\text { 万円) } \\
\mathrm{N}=2874 \\
\end{array}$ & 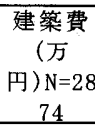 & $\begin{array}{c}\text { 敷地面 } \\
\text { 積 } \\
\left(\mathrm{m}^{2}\right) \mathrm{N}= \\
2781\end{array}$ & $\begin{array}{c}\text { 延床面 } \\
\text { 積 } \\
\left(\mathrm{m}^{2}\right) \mathrm{N}= \\
2874\end{array}$ \\
\hline 北海道 & 50.5 & 78 & 1007 & 1790 & 2665 & 395.0 & 171.6 \\
\hline 重北 & 47.5 & 636 & 1317 & & 2719 & 409.8 & \\
\hline 関東 & 50.8 & & 1505 & & 26 & 252.1 & 149.5 \\
\hline 北陸 & 47.6 & 585 & 1093 & 1643 & 2605 & 315.9 & 166.9 \\
\hline 中部 & 45.8 & 621 & & & 2670 & 302.4 & 160.7 \\
\hline 近盎 & & & 1496 & 115 & 2529 & 238.0 & 151.5 \\
\hline 中国 & 47.7 & 581 & 1285 & 13 & 2510 & 308.2 & 153.7 \\
\hline 四国 & 49.7 & 575 & 17 & & 2508 & 359.5 & 155.9 \\
\hline 九州 & 49.2 & 623 & & & 2357 & 339.7 & 150.5 \\
\hline 全国 & 49.1 & 658 & 1399 & 1338 & 2608 & 282.1 & 154. \\
\hline
\end{tabular}


いという結果が得られた。

\section{4. 結譮}

本研究で得られた分析的知見を以下に示す。また、新設着 エにおけるプレハブ戸建持家建替住宅と購入者層の平均像を 表 12 に示す。

\section{1.プレハブ戸建持家の建替率と建替住宅の特性}

(1) 新設着工におけるプレハブ戸建持家住宅の全国平均的な建 替比率は $26.5 \%$ であり、この值は新設着工持家住宅市場におけ る再建築率の全国平均 $28.3 \%$ に近い位置にある。プレハブ戸建 持家の建替率が高い関東、中部、近畿、四国は、新設着工持 家住宅の再建築率も高い地域に当る。プレハブ戸建持家市場 における建替率の状況は実態を反映しており、新設着工持家 市場と同様な傾向にあると言える。

（2）プレハブ戸建持家建替住宅は在来木造住宅やプレハブ戸建 持家の非建替の住宅に比べ、規模が広く、建築費が高額の方 に移行している。言い換えれば、戸建建替住宅は新設戸建持 家市場ではグレードの高いレベルにあると言える。また、プ レハブ戸建建替の敷地対応力については、非建替の一次取得 との比較から、狭小敷地への適応も向上している。このこと は、プレハブ住宅の設計自由度の特性に位置づけられると言 える。

\section{2. プレハブ戸建持象建替住宅の戝入者の特性}

（1）プレハブ戸建住宅における建替層は、平均年齢は 40 歳代後 半から 50 歳前半の購入者であり、平均年収も高い。建替の平 均建築費は購入者の平均年収の 4.0 倍であり、新設着工住宅市 場における一般のマイホーム購入費の平均年収倍率 4.4 倍を下 回る。それに伴い資金計画における自己資金率も高くなって いる注8)。

（2）建替層の住宅建設動機は、従前家屋の狭小・老朽化と二世 帯同居が最大の要因であり、建替の主たる目的は住宅の質の 向上にあると言える。言い換えれば、建替住宅は、居住性や 耐久性等の性能低下による除去した住宅に対するストックの 補充、多世帯住宅への対匛等が建替需要の主要要因になって いると言える。

尚、プレハブ住宅の特性における地域要因や他種別住宅と の建築費の格差の要因等についての分析は、今後の研究課題 である。

\section{謝辞}

本研究の調查にご協力を頂いた多くの方々に、ここに梁く 感謝の意を表わします。

また、全文にわたり、查読者から有益なご指摘を頂きまし た。ここに記して梁謝します。

\section{注积}

1）平成 15 年度住宅着工統計によると、全国の非木造プレハブ持家住宅は 49 , 769 戸で、非木造持家住宅全体 71,930 戸の約 $69.2 \%$ を占める。

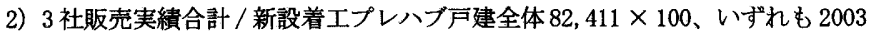
年度の戸数である。

3）新設着工住宅市場の都道府県別 - 利用関係別（又は用途別）・構造別に
分類した床面䄼と建筑予定金額の利用可能なデー夕は国土交通省「建築統 計年報」のみである。但し、同年報では、居住専用建築物と表現している。 そのため、本稿では、同年報の「都道府県別、構造別、用途別一建築物床 面積の合計、工事費予定積」と記した情報から「居住専用建築物」のデー 夕を利用した。

4）国土交通省の「建築統計年報」の居住専用建築物は、居住専用住宅の 他に、居住専用淮住宅を含む。平成 $12 \sim 13$ 年度の 2 年間には、居住専用

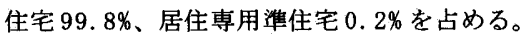

5) 国土交通省「平成 15 年住宅需要実態調査」の結果では、現在一緒に住 んでいる世帯人員だけから考虑した「世带の型」を次の 5 つに分類してい る。(1)単身世帯、(2)核家族世帯（夫婦のみ、親と年齢別の子供計6タイプ）、 (3)三世代世帯、(4)複合世带、(5)その他。これには二世帯の分類はないが、 3 世代と複合の世带を含む多世帯の地域別状況を下表に示す。

<参考>「平成 15 年住宅需要実態調査」よりの分析結果 $\nabla$ 地域別家族形態に占める 3 世代、複合世帯の構成比

\begin{tabular}{|c|c|c|c|c|c|c|c|c|}
\hline \multirow{2}{*}{ 地域 } & \multicolumn{4}{|c|}{ 珄 数 } & \multicolumn{4}{|c|}{ 楎成比 } \\
\hline & 全件 & 3世代世帯 & 複合世帯 & 小計 & 全件 & 3世代世帯 & 複合世带 & 小計 \\
\hline 北海道 & 2220 & 128 & 85 & 213 & 100 & 5.8 & 3.8 & 9.6 \\
\hline 東北 & 3254 & 521 & 264 & 785 & 100 & 16.0 & 8.1 & 24.1 \\
\hline 関東 & 16875 & 1378 & 707 & 2085 & 100 & 8.2 & 4.2 & 12.4 \\
\hline 中部 & 5149 & 691 & 265 & 956 & 100 & 13.4 & 5.1 & 18.6 \\
\hline 北陸 & 1590 & 304 & 127 & 431 & 100 & 19.1 & 8.0 & 27.1 \\
\hline 近畿 & 8238 & 643 & 315 & 958 & 100 & 7.8 & 3.8 & 11.6 \\
\hline 中国 & 2926 & 275 & 179 & 454 & 100 & 9.4 & 6.1 & 15.5 \\
\hline 四国 & 1511 & 180 & 76 & 256 & 100 & 11.9 & 5.0 & 16.9 \\
\hline 九州·沖縄 & 5248 & 493 & 255 & 748 & 100 & 9.4 & 4.9 & 14.3 \\
\hline 全国 & 47011 & 4613 & 2273 & 6886 & 100 & 9.8 & 4.8 & 14.6 \\
\hline
\end{tabular}

6）年収倍率は建築費をその世带主の年収で除したもの。

7) 住宅金融公庫利用者一戸建注文住宅平均購入価格 2622.8 万円 / 棟（土地 取得のための借入のない者、2000 年度の $2,648.6$ 万円、2001 年度の $2,596.9$ 万円の平均）に対し、融资利用者本人の当時平均年間収入額の 597.3 万円 (2000 年度の 606.4 万円と 2001 年度の 588.1 万円の平均) で除した值。

8) プレハブ戸建建替層の建築費に占める自己資金率平均が $53.6 \%$ （自己資 金 1,399 万円 / 建築費 2,608 万円 $* 100)$ に対し、プレハブ戸建一次取得層 のそれが $29.5 \%$ （自己资金 636 万円 / 建築費 2,157 万円 $* 100$ ) であり、また、 工法・構造を問わない住宅金融公庫利用者一戸建注文住宅の購入時の平均 自己資金率は $29.5 \%[(2000$ 年度 764.3 万円 +2001 年度 783.8 万円の平均 $)$ 774.1 万円/ (同) 2622.8 万円*100] である。

\section{省考文献}

1) 国土交通省 : 月刊「住宅着工統計」，2005.2

2）東樋口護，加藤裕久：戸建プレハブ住宅の施工体制（部品化による住宅供 給の成立条件に関する研究)，日本建築学会学術講演梗概集，F-1 分冊 ,pp. $1739 \sim 1740,1980$

3）東樋口護：プレハブ住宅市場と価格政策 -プレハブ価格に関する研究， 日本建築学会計画系論文集, No. 281, pp. $145 \sim 150,1979.7$

4）西成田直人，吉田倬郎：プレハブ住宅の性能・構法の最近の動向につい $\tau$, 日本建築学会学術講演梗概集, F-1 分冊, pp. $1121 \sim 1122,2003.9$ 5) 岩㠃琳, 多治見左近, 西村一朗:プレハブ戸建注文住宅と顧客属性の特徵 に関する研究，日本建築学会技術報告集, No. 19, pp. 303-306, 2004. 6 6) 岩浐琳, 西村一朗: 三大都市圈の新規供給プレハブ戸建注文住宅におるける持 家加らの住替層の特性に関寸る研究, 都市住宅学, No. 47, pp. 29-34, 2004. 10 7) 岩浐琳, 多治見左近, 西村一朗: 新設プレハブ戸建建売住宅と購入者の特 性に関寸る研究，日本建築学会技術報告集, No. 20, pp. 315-318, 2004. 12

8）国土交通省総合政策局: 住宅着工統計による再建築状況について, 各年度 9）国土交通省監修、(財) 建設物価調查会: 建築統計年報，2003 年度 10）亀井靖子, 曽根陽子：1970 年代の民間建売住宅・団地の增改筑・建替 に関する研究, 日本建筑学会計画系論文集, No. 571, pp. $17 \sim 23,2003.9$ 11）增田達男, 玉置伸悟：金沢市既成市街地に於ける戸建建替住宅に関寸 る研究, 日本建築学会梗概集, E-2 分冊, pp. $253 \sim 254,2003$

12）飯田雅史, 菊池弘明: 北海道の建替え住宅に関する調查研究, 日本建築 学会計画系論文集, No. 584, pp. $21 \sim 25,2004.10$

13）（株）彰国社，建築大辞典 第 2 版，1993.6

14）(社）日本住宅協会: 住宅需要の動向 平成 15 年住宅需要実態調查の結 果, 2004.9

15）住宅金融公庫：公庫融資利用者調查報告マイホーム新築融資編，2000 年 度、2001 年度

16）松村秀一：「住宅」という考え方 20 世紀的住宅の系譜, pp. 154-163, 東京大学出版社, 1999.8 